\title{
Korean University Students' Attitudes and Motivation towards Studying English
}

\author{
Aaron J. Geddes \\ Department of Liberal Arts, Hongik University, South Korea
}

Copyright $(2016$ by authors, all rights reserved. Authors agree that this article remains permanently open access under the terms of the Creative Commons Attribution License 4.0 International License

\begin{abstract}
The main objective of this study was to identify the attitudes of Korean university students towards studying English and to determine if attending after-school English academies has had a negative impact on their attitudes towards studying English. The study also sought to determine if studying English leads to anxiety, and more importantly if important examinations, such as the TOEIC and TOEFL tests were responsible for increasing anxiety. An attempt was also made to see if students were more intrinsically or extrinsically motivated and what the most important reasons for studying English were. Fifty-two university students from a single university were chosen using cluster sampling. Each student was given a survey consisting of twenty-seven Likert-scale and one Likert-type questions, and was also responsible for ranking reasons for studying English. The study found that students had a general positive attitude towards studying English and those who had previously attended private English academies for short periods of time had the most positive attitude towards studying English. It was also found that studying English, as well as studying for TOEIC and TOEFL tests, did not lead to anxiety. As well, it was suggested that while an extrinsically motivated reason, getting a better job, was the most important reason for studying English, intrinsic and extrinsic motivation were found to be about equal.
\end{abstract}

Keywords Korean Education, English Language Education, Motivation for Learning English, Attitude towards English

\section{Introduction}

In Korea, English is becoming ever more prominent in the everyday lives of Koreans. English is often of such importance that it makes headlines in newspapers. There have even been such headlines as "Kids Say Learning English Stressful"[1], "English Haunts Korea"[2], and "Petition Protests English Expansion Plan"[3]. Parents will often do anything to help their children's acquisition of
English even if it means going to extreme measures, such as the previous procedure of getting their children tongue surgery to help the pronunciation of English words. This has made headlines internationally, such as "Children's surgery to speak better English"[4] and "S. Koreans Accent Surgery in Bid for Flawless English"[5]. There are even other articles which present arguments, such as "We must not forget that English proficiency is also a big stress and expected to become bigger as more companies are pursuing globalization.'[6] English is becoming more and more important to obtain employment, especially in business.

As Korea has embraced 'English fever,' as Park[7] has described it, as a symptom of the overall 'education fever,' students spend increasing amounts of time studying English, generally in private academies after normal school hours. Often starting as early as four years of age, there seems to be a growing trend for students to develop negative attitudes studying English. It would appear that the strong emphasis placed upon taking systemized English tests, such as the TOEIC or TOEFL, even for jobs which do not utilize English, may have a role in this negativity. It also appears that the over emphasis of the importance of English as something that must be learned to fluency may also play a role in the negativity.

While the amount of time spent studying English and the amount of importance put on English in Korea may affect learners' attitudes towards studying English, there are also other factors that possibly affect how learners feel about learning English. As English in Korea is inextricably linked to America, the push to learn directly from native English speaking teachers has led to an influx of teachers from English speaking countries. With a large number of native English speaking teachers coming from America, Koreans are ever more exposed to Americans and American culture. As the public attitude towards America tends to fluctuate within Korea and English being linked to America, it is important to understand if students' attitudes towards studying English could very well be affected by feelings of anti-Americanism. Further, as the prevalence of native English speaking teachers is becoming more predominant, it appears to be creating a divide between those who do and do 
not have access to these teachers, both regarding levels of English and attitude towards studying English as those who have native English speaking teachers have a more favourable attitude towards studying English.

Understanding how all these different factors affect the attitudes and motivation of English language learners in Korea is important in moving forward and creating the optimum environment for students to effectively learn English while also maintaining a thriving English education industry.

\section{Objectives}

The main objective of this study was to identify attitudes of Korean university students towards studying English, and to determine if factors, such as previous attendance at after-school English academies, gender, and attitude towards Americans and American culture have an impact on attitudes towards studying English. Further objectives were to look at other factors affecting students' attitudes towards English, as well as looking at the role of English in Korea. As a final objective, this study aimed to determine what students find as the most important reasons for studying English and to look at the importance of extrinsic motivation and intrinsic motivation in students' studies.

\section{Literature Review}

Motivation and attitude are two very important aspects of the learning process. In the field of language learning, this is no different. Understanding how motivation affects attitude and then how attitude affects achievement is extremely important in a second language classroom. Rubenfeld et al. [8] state that there are two different kinds of motivation that are used in learning: extrinsic and intrinsic motivation. Deci[9] refers to an "externally mediated activity or constraint" to describe extrinsic motivation and Rubenfeld et al[8] states that "Extrinsically motivated activities are a means to an end." As an example, it is explained that learning an L2 (A person's second or target language being learned) in order to attend university classes in the L2 is an example of extrinsic motivation. In regards to intrinsic motivation, Deci and Ryan[10] state, "Intrinsic motivation refers to motivation to fulfill a task that leads individuals to feel a sense of personal enjoyment and control when taking part in the task. When individuals' motivations are self-determined, they become more involved in activities and make efforts to reach challenging goals"[p. 309] Rubenfeld et al.[8] follows this up by saying that as opposed to extrinsic motivation being a means to an end, intrinsic motivation is an end in itself and explain that learning an L2 with the intent to enhance ones sense of belonging to the L2 community is an example of intrinsic motivation.

Rubenfeld et al.[8] argue that learning an L2 for intrinsic reasons is linked to greater motivational intensity, a higher likelihood in continuing L2 education, and greater proficiency in both speaking and reading. Vansteenkiste, Simons, Lens, Sheldon, and Deci[11] found that greater academic achievement occurred when language activities were presented as an intrinsic goal rather than an extrinsic goal. Further, Sheldon et al [cited in 8], "have found that self-determined motives and intrinsic goal contents uniquely predict positive well-being whereas controlled motives and extrinsic goal contents uniquely predicted negative well-being."[p. 312] Liu[13] found that in China "when evaluating EFL learners, more proficient EFL learners reported significantly more intrinsic interest, and less proficient EFL learners were significantly more driven by immediate achievement." [p. 19] While both types of motivation are useful within the second language classroom, it has been shown that intrinsic motivation has a stronger relationship to positive attitude than extrinsic motivation. Therefore, intrinsic motivation should be strongly encouraged amongst second language learners.

As intrinsic motivation is often linked with the desire to better understand the target language cultural group, the desire to integrate into the target culture itself plays an important role in the attitudes of learners. Gardner[14] states that learning an L2 is "not simply learning new information (vocabulary, grammar, pronunciation, etc.) which is part of [one's] own culture but rather acquiring symbolic elements of a different ethnolinguistic community."[p. 311] According to Gardner[14] because learning an L2 requires the learner to include the aspects of a different culture into their own life, "the student's harmony with his own cultural community and his willingness or ability to identify with other cultural communities become important considerations in the process of L2 acquisition."'[p. 312] It is argued that the acculturative changes individuals make when coming into contact with each other are relevant to individual experience of learning L2 [8] and further these experiences are important because they can impact stress[15] and psychological well-being[16]. As shown, it is important to instill a sense of openness towards the target culture in second language learners to help strengthen intrinsic motivation, and therefore, encouraging a positive attitude.

Cook (2000, cited in [17]) states the three main factors in second-language acquisition (SLA) are age, personality and motivation. Lightbown and Spada (2001, cited in [17]) define motivation in SLA as "a complex phenomenon which can be defined in terms of two factors: learners' communicative needs and their attitudes towards the second language community."[p. 8] Zhou[17] states that when learners feel the need to communicate or fulfill professional ambitions using their $\mathrm{L} 2$, they will be motivated to acquire it. Gardner and Lambert (1972, cited in [17]) defined this as integrative motivation and instrumental motivation. They follow that integrative motivation "refers to learning the language in order to take part in the culture of its people. And instrumental motivation means a learner learns the language for a career goal or other practical reason" [14, p. 8]. Zhou[17] states that if a student has integrative motivation he will look 
for opportunities to learn about the target language, culture, and people and will become more successful in the L2 classroom. Lightbown and Spada (cited in [17]) state, "If the speaker's only reason for learning the second language is external pressure, internal motivation may be minimal and general attitudes towards learning may be negative."'[p. 8] Integrative motivation is shown to be very important in the second language classroom, and like intrinsic motivation, is related to a positive attitude and success with the target language, and should therefore be encouraged and nurtured within the classroom.

Separating integrative and instrumental motivation has shown to be difficult to sometimes define. Kormos and Csizer[18] claimed that problems exist when defining the idea of integrative motivation, especially in regards to English in the $21^{\text {st }}$ century. Kormos and Csizer[18] state a "high number of students learn an L2 in a foreign language setting with the purpose of being able to communicate with other nonnative speakers in an international environment." $[p$. 330] This is especially true in the case of English, which has become an international language serving as a lingua franca in a globalized world [19][20]. This means that integrative motivation is not necessarily concerned with adapting to another culture, as much as it is, as Yashima [21] states an, "interest in foreign or international affairs, willingness to go overseas to study or work, readiness to interact with intercultural partners... and a non-ethnocentric attitude toward different cultures." Kormos and Csizer[18] also argued that in the case of English, it can also be difficult to distinguish instrumentality because as Lamb[22] explains, "meeting with westerners, using pop-songs, studying and traveling abroad, pursuing a desirable career - all these aspirations are associated with each other."[p. 331] Kormos and Csizer[18] argue that for a large number of language learners, identification with native speakers of the target language does not seem to be a relevant factor in motivation. It is argued that "as a consequence of English becoming a world language, the pragmatic benefits deriving from being able to speak this language and the attitudes of "World English" community have become intricately linked, which has rendered the separation of integrativeness and instrumentality problematic" $[18$, p. 331]. Aside from these difficulties, it can still be useful to look at both integrative and instrumental motivation when looking at students' attitudes towards studying English.

Kormos' and Csizer's research found that one's image as a successful user of their L2 in the future was intricately linked to attitude towards language learning. It was also found that in an Asian setting, the students' attitudes towards the role of English in an internationalized world are extremely important in L2 learning. This is very important when looking at Korea's situation concerning the studying of English, especially on the grand scale that it is studied in Korea.

The instructor of a language course also plays a large role in the attitude and motivation of students, in both nurturing positive attitudes towards the target language, but also in general communication. Noels et al. (cited in [18]), "found that students enrolled in a French as a second language program who perceived their language teacher's communication to be positive and informative were more intrinsically motivated to learn an L2 than students who perceived their teacher's communication to be controlling."[p. 312]

Zhou [17] maintains that if the instructor is positive and friendly, and appears eager in the classroom, and if a learner's classmates admire him for his ability, he will study harder and increase his intrinsic motivation. Zhou[17] claims that by increasing intrinsic motivation, the learner's attitude towards the L2 will also improve. Cook (cited in [17]) summarizes that "according to Gardner, integrativeness and attitudes lead to motivation; motivation and aptitude lead to success. Each causes the other."[p. 10] It has been shown that the role of the teacher is very important in the attitude and motivation of children. In regards to educators, research has shown that positive communication from the educator has a strong impact on the attitudes and motivation of students. These findings support those of Park and Lee[23] that negative criticism of language ability was linked to anxiety when it came to oral communication.

In a study conducted by Kobayashi[24], the role of gender in Japan was studied to determine whether it played a role in attitude towards studying English. It was found that female Japanese university students had more favourable attitudes to studying English. Kobayashi quotes a study done by Powell and Batters[24] which researched the popularity of foreign language learning in the UK, in which the largest decline was amongst boys. The study found that female students have more positive attitudes towards studying foreign languages. Another finding in the USA by Sung and Padilla (cited in [24]) showed that female students were also more motivated to learn Asian languages compared to male students. Matsui (cited in [24]) claimed "Japanese female university students perceived their life in the USA as an experience of 'cultural exploration' and 'self-emancipation"'[p. 191] and Japanese women's marginalized status within Japanese society allowed them greater opportunity and freedom to study a foreign language. In the end, Kobayashi[24] found that the different attitudes between Japanese men and women towards studying English could be attributed to women's marginalization within Japanese mainstream society, fewer social constraints in regards to departing from the society, and the use of a foreign language as an effective tool to achieve better lives. As Korean society has many similarities to Japanese society, especially in terms of gender roles, albeit to a lesser extent, Kobayashi's research could be very important to understanding the attitude towards English study within Korea.

As is the case in many Asian countries, the importance of English ability is becoming more significant, especially as international business becomes more prominent. As the importance for English ability expands, there is ever more competition to acquire English fluency. In current research by Yee and Young[25] on the situation in Macao, it was 
found that the importance of English has been growing since its 1999 return to China. Within Macao, English has never been the lingua franca, as it is in Hong Kong, but it is still used as a neutral language for intercultural interactions within the community, and it used as the language of instruction in universities. Yee and Young[25] wanted to find what the attitudes of the university students were towards English and English learning in Macao, and to find if there were any differences between Macao-born Chinese and Mainland-born Chinese university students towards English learning in Macao.

Yee and Young[25] found that Macao-born students saw English as very important to post-1999 Macao. Some very interesting results were discovered through Yee's and Young's research. First, they found that students had "neutral responses to items indicating instrumental motivation.'[p. 485] In response to being asked, 'I learn English because I want to pass examinations', most respondents disagreed and it was shown to not be an important factor in motivation to learn English. As well, while more students agreed that they learned English to find better jobs, supporting finds by Friedrich[26] that English has a strong association to the job market, there still was not strong agreement and its importance was about equal to the love of just talking to foreigners.

Yee and Young[25] found that overall, "the surveyed university students attached importance to learning English. They did not believe that English learning would threaten their identity as Chinese, nor did they think English had a lower status than the two official languages of Macao."[p. 483] It was also found that Macao-born students placed great importance on integrative reasons for studying English. Some of the findings that Yee and Young[25] found were that students strongly agreed with the following statement: 'The command of English is very helpful in understanding foreigners and their cultures.' As the research revealed, integrative reasons appeared to have a significant relationship with positive attitude in that both were quite strong in Macao.

From the survey given to Chinese students studying English in Macao, the most strongly agreed upon statements were: Macao people should learn English; The use of English is important to the success of Macao's development; The command of English is very helpful in understanding foreigners and their cultures; Macao people should learn American/British English; I wish I could speak fluent and accurate English, and; I would learn English even if it were not a compulsory subject in university.

As the Macao study shows, university students put great importance into the learning of English, and that it would be very important for the future development of Macao. While importance was placed upon extrinsic reasons for learning English, they didn't appear to be any more important than intrinsic reasons. Also, while importance was placed upon integrative reasons for learning English, instrumental reasons were not given great importance. As shown, attitudes towards English were quite positive in Macao, and integrative motivation played a more significant role than instrumental motivation among university students. It could thus be reasoned that integrative motivation and positive attitude are positively related.

In research regarding the affective variables in learning a second language, Ryu's[27] study of Korean university students stated that when learning a foreign language, not only are cognitive abilities important, but the affective variables of studying are also very important. The purpose of the study was to show that attitude and motivation can affect achievement in language study. The research stated five hypotheses regarding language study and what affects achievement: if one has a good attitude towards native English speakers, it affects achievement; positive attitude towards English affects achievement; positive attitude towards English teachers affects achievement; intrinsic motivation affects achievement, and; extrinsic motivation affects achievement.

Macnamara (cited in [27]) argued positive attitude will bring positive effects and negative attitude will bring negative effects. This was supported by Rubin and Thompson (cited in [27]) who argued positive attitude generally keeps you interested in learning languages. Ellis (cited in [27]) claimed that if learners want to put themselves into the culture and adapt to the target culture, their achievement will improve. Ryu[27] found that attitude towards native English speakers was not related to achievement; however, positive attitude towards English and English teachers were both positively related to achievement. As well, it was found that both intrinsic and extrinsic motivation was positively related to achievement; however, intrinsic motivation had a stronger relationship to achievement than did extrinsic motivation.

Lee[28] researched Koreans' motivation towards studying English and their attitudes towards the English language and American people. The researcher compared different age groups to see how motivation and attitude differed. At all age groups, the importance of English and the need to learn it was strongly expressed by English Language Learners (ELL). Lee[28] found that in all age groups, instrumental motivation was much stronger than integrative motivation, but that as ELLs get older, integrative motivation grows in response to having more freedom to study. Lee's [28] research showed that for high-school and middle-school students, the main motivation for studying English was to pass tests, mainly focusing on the university entrance examination. However, for university students and adults, the greatest motivation was to try and better their careers.

These findings are in support of those of Duvernay[29] who found that from an early age Korean students have the view that English is needed for a successful career, domestically or internationally, and that other extrinsic factors, such as parents sending children to camps and private academies, are what plays the prominent role in students learning English. It was also found by Duvernay that although instrumental and extrinsic reasons played the strongest role in learning English, integrative and intrinsic 
reasons are growing stronger in Korea as western culture becomes more prominent.

As Lee[28] looked into the attitudes of Korean ELLs, it was found that there was a strong sense of dissatisfaction and a general negative attitude towards studying English and towards Americans. One main reason the researcher found for the level of dissatisfaction was that the Korean English education system didn't match the goals of the students. While students preferred to focus on studying communicative techniques due to its participatory nature, the government's preference was placed upon passive techniques that were not conducive to participation. Flattery[30] noted the difficulty in implementing communicative methods in Korea as they are seen as overly western and inappropriate for Korean students in a socio-cultural context. Lee[28] also found that all students showed a strong sense of dissatisfaction with their middle and high school English classes and found them too difficult, and students needed to rely on private academies, which are private schools students usually attend after school hours to further study, in order to meet schools' requirements.

This general negative feeling towards Americans was supported by research done by $\operatorname{Kim}[31]$ who found that among high school students in Korea, more students had a negative attitude towards Americans than had a positive and also found that the negative attitude towards English learning was stronger than the positive. Kim[31] also found there to be a positive correlation between attitude towards Americans and English proficiency. This anti-American sentiment was also found to be one of two Korean-specific factors, the other being preparation for the university entrance exam, that clearly affect the motivation and attitudes of Korean high school students towards learning English.

Lee's [28] research led to some suggestions to help improve both motivation and attitude towards studying English. One such suggestion was to focus more on communicative techniques to give learners an opportunity to speak and to make them more willing to participate. Second, middle and high school students should be taught to be more open-minded towards other cultures, including Americans and American culture. Third, in order to improve integrated motivation it should be emphasized to middle and high school students that they will need English to live in a global world.

Chang[32] researched Korean university ELLs' attitudes towards the current English 'boom' phenomenon and learner anxiety. The research delved into the current push to obtain high scores on TOEIC (Test of English for International Communication) and TOEFL (Test of English as a Foreign Language) tests and the anxiety that accompanies taking these tests. Chang[32] found that anxiety caused by taking both the TOEIC and TOEFL tests was largely due to the inordinate amount of importance put upon obtaining high scores to find employment. Arnold and Brown (cited in [32]) claimed anxiety is one of the most powerful affective factors and is related to fear, frustration and nervousness. Scovel[33] found that there were two kinds of anxiety: facilitating and debilitating. "Facilitating anxiety motivates the learner to 'fight' the new learning task; it gears the learner emotionally for approach behavior. Debilitating anxiety, in contrast, motivates the learner to 'flee' the new learning task; it stimulates the individual emotionally to adopt avoidance behavior."[p. 11] It was found that emphasis on test results was positively related to anxiety, and was leading to ELLs avoiding English language study in an attempt to avoid the debilitating anxiety that accompanies English language study. Chang[32] also found that the build up of anxiety negatively affects communication ability and increases negative attitudes towards English. Liu[34] found anxiety to be a very important factor in language acquisition as learners who had more anxiety in the classroom tended to have lower motivation and that foreign language anxiety was a strong predictor of foreign language proficiency.

Chang[32] suggested that the anxiety accompanying English language study was caused because communication levels were not at the desired levels and students felt they should be better at English than they really were. Liu[34] came to the same findings that because communication ability did not match that of the desired level, students felt more anxiety and lacked confidence when speaking English in the classroom. Yim and $\mathrm{Yu}$ [35] suggested teaching methods that boosted self-confidence would lessen anxiety and Chang[32] found that because output was not matching input, teaching methods were wrong and claimed that anxiety could be reduced by changing teaching techniques to be more communicative based. Chang's research closely resembles the findings of Dörnyei[36], in which studies on motivational strategies revealed that teachers, materials and activities are extremely important in shaping learner attitudes.

As it has been shown, there are many factors which can affect students' attitudes. Extrinsic motivation and intrinsic motivation, as well as, instrumental motivation and integrative motivation are found to be important factors in attitudes. While both are important, intrinsic and integrative motivation are both found to be more related with a positive attitude than extrinsic and instrumental motivation. Looking at gender, it was also found that females are more likely to have a positive attitude towards second language study, especially in Asia. In Macao, it was also found that English was seen as very important for development and that people placed great importance in learning English. As well, English was seen as being very useful for understanding foreign cultures. It was also found that integrative reasons were much more important and were accompanied by a very positive attitude towards studying English.

In research conducted in Korea, integrative reasons were seen to become more important as English learners got older and at the university level, bettering their careers was the most important reason for studying English. It was also found that there was a general negative feeling towards Americans and American culture. Lastly, it was shown that important examinations, such as the TOEIC and TOEFL tests, led to anxiety and that learners were also not satisfied with their English language ability. 


\section{Materials and Methods}

\subsection{Subjects}

In total, 52 students were selected for this study. There were 35 males and 17 females. Students all attended mandatory English classes at Hongik University. Cluster sampling was used selecting six separate classes. Most students had received English instruction since grade three of elementary school and 34 students had received instruction from private academies.

\subsection{Instrumentation}

The survey given to the participants was translated into Korean and double-checked for translation accuracy. Participants were asked to answer information regarding previous private academy attendance and asked to rate their general attitude towards studying English on a four-point scale: very positive, positive, negative, and very negative. Participants also answered a Likert scale survey consisting of 24 questions. The Likert Scale consisted of 4 options: strongly agree, agree, disagree, and strongly disagree. Participants were asked to answer questions regarding attitude, attitude towards native English teachers, attitude towards academies, and attitude towards the importance of testing, as well as other types of questions regarding attitude on the Likert scale. Participants were also asked to rank in order the importance of different reasons for studying English.

\subsection{Procedure}

The surveys were handed out to the participants during their classes and were completed and returned during the class. The surveys were collected anonymously and confidentially so participants knew that their personal information would not be linked to them.

\subsection{Data Analysis}

A mean was taken for all Likert scale questions on a scale where: strongly agree $=1$, agree $=2$, disagree $=3$, and strongly disagree $=4$. The general attitude was similarly analyzed: very positive $=1$, positive $=2$, negative $=3$, and very negative $=4$. The ranking of importance of different reasons for studying English was analyzed on a six-point scale, with a numerical value equal to the ranking assigned to each answer. The means were displayed in tables; for a total of eight tables.

\section{Results}

\section{Students' Attitudes towards Studying English in Korea}

What are the attitudes of university students towards English and learning English in Korea? To answer this question participants were asked to rate their general attitude towards studying English on a four-point scale, one being very positive and four being very negative. As shown in table 1 , the mean for all participants surveyed was 1.89 , being slightly more than positive. Looking into factors that might have effects upon attitude, previous private academy attendance, gender, and attitude towards Americans and American culture were looked at.

Table 1. General attitude towards studying English

\begin{tabular}{|l|c|}
\hline & $\begin{array}{c}(\mathrm{N}=52) \\
\text { Mean }\end{array}$ \\
\hline Rate your general attitude towards studying English. & 1.89 \\
\hline
\end{tabular}

As shown in table 2, it was found that participants who had attended private English academies for over two years had the least positive attitude towards studying English, with a mean of 2.07. Participants with no previous private English academy attendance had a mean of 2.00. Participants who had attended for less than two years had the most positive attitude towards studying English, with a mean of 1.6.

Table 2. General attitude towards studying English by previous private academy attendance

\begin{tabular}{|c|c|c|c|}
\hline & $\begin{array}{c}\text { No private } \\
\text { academy } \\
\text { attendance } \\
(\mathrm{N}=18) \\
\text { Mean }\end{array}$ & $\begin{array}{c}1 \text { to } 2 \\
\text { years } \\
\text { private } \\
\text { academy } \\
\text { attendance } \\
(\mathrm{N}=17) \\
\text { Mean }\end{array}$ & $\begin{array}{c}\text { Over } 2 \\
\text { years } \\
\text { private } \\
\text { academy } \\
\text { attendance } \\
(\mathrm{N}=17) \\
\text { Mean }\end{array}$ \\
\hline $\begin{array}{c}\text { Rate your general attitude } \\
\text { towards studying English }\end{array}$ & 2 & 1.6 & 2.07 \\
\hline
\end{tabular}

Looking at gender, as shown in table 3 , it was found that female participants had a more positive attitude towards studying English than did male participants. Female participants had a mean of 1.79 and male participants had a mean of 1.94 .

Table 3. General attitude towards studying English by gender

\begin{tabular}{|c|c|c|}
\hline & $\begin{array}{c}\text { Male } \\
(\mathrm{N}=35) \\
\text { Mean }\end{array}$ & $\begin{array}{c}\text { Female } \\
(\mathrm{N}=17) \\
\text { Mean }\end{array}$ \\
\hline $\begin{array}{c}\text { Rate your general attitude towards studying } \\
\text { English }\end{array}$ & 1.94 & 1.79 \\
\hline
\end{tabular}

Regarding attitude towards Americans and American culture, students were asked to respond, with a level of agreement, to the following statement:

- I have a positive view towards American culture and Americans.

Table 4. General attitude towards studying English by attitude towards Americans and American culture

\begin{tabular}{|c|c|c|}
\hline & $\begin{array}{c}\text { Strongly agree or } \\
\text { agree to a } \\
\text { positive view of } \\
\text { Americans and } \\
\text { American culture } \\
(\mathrm{N}=38) \\
\text { Mean }\end{array}$ & $\begin{array}{c}\text { Strongly disagree } \\
\text { or disagree to a } \\
\text { positive view of } \\
\text { Americans and } \\
\text { American culture } \\
(\mathrm{N}=14) \\
\text { Mean }\end{array}$ \\
\hline $\begin{array}{l}\text { Rate your general attitude } \\
\text { towards studying English }\end{array}$ & 1.75 & 2.23 \\
\hline
\end{tabular}


It was found that students who had a positive attitude towards Americans and American culture also had a more positive attitude towards studying English. As shown in table 4, participants who strongly agreed had a mean of 2.14 , students who agreed had a mean of 1.65 , and participants who disagreed and strongly disagreed (only one participant) had a mean of 2.23.

\section{Factors Affecting Students'Attitudes towards Studying English}

What classroom factors affect the attitude of students? Participants were asked to respond, with a level of agreement, on a four-point scale, to the following statements:

- Having a native English teacher has a positive effect on my attitude.

- Having a Korean English teacher has a positive effect on my attitude.

- Studying English at private academies has a positive effect on attitudes.
- If the instructor uses positive communication, my attitude will become more positive.

- In Korea, English teaching methods are effective.

As shown in table 5, participants strongly agreed that having a native English teacher has a positive effect on attitudes, with a mean of 1.44 . There was much less agreement concerning a Korean English teacher having a positive effect on attitudes, with a mean of 2.17. Looking at participants who had previously attended private academies, there was agreement that studying English at private academies has a positive effect on attitudes, with a mean of 2.00. It was also found that participants strongly agreed that if an instructor uses positive communication, their attitude will also become more positive, with a mean of 1.46. Also, while not directly related to attitude, participants disagreed that the English teaching methods used in Korea are effective, with a mean of 2.84 .

Table 5. Rank orders and mean for students responses to the questionnaire items*

\begin{tabular}{|c|c|c|c|}
\hline \multicolumn{2}{|r|}{ Items } & \multicolumn{2}{|c|}{$(\mathrm{N}=52)$} \\
\hline & & Rank & Mean \\
\hline 1 & Having a native English teacher has a positive effect on my attitude. & 2 & 1.44 \\
\hline 2 & Studying English at academies has a positive effect on attitudes. & 14 & 2.08 \\
\hline 3 & Having a Korean English teacher has a positive effect on my attitude. & 17 & 2.17 \\
\hline 4 & I feel uneasy when speaking English to a native speaker & 9 & 1.94 \\
\hline 5 & I feel comfortable when using English & 23 & 2.98 \\
\hline 6 & It embarrasses me to volunteer answers in our English class. & 21 & 2.71 \\
\hline 7 & I wish I could speak fluent and accurate English. & 1 & 1.02 \\
\hline 8 & I really enjoy studying English & 12 & 2.02 \\
\hline 9 & I would learn English even if it were not a compulsory subject in university & 6 & 1.6 \\
\hline 10 & Studying English will help me to understand people from all over the world. & 9 & 1.94 \\
\hline 11 & You would like to become similar to people who speak English as a native language & 11 & 2 \\
\hline 12 & I have a positive view towards American culture and Americans & 15 & 2.13 \\
\hline 13 & I learn English because I want to pass examinations (TOEIC, TOEFL) & 13 & 2.04 \\
\hline 14 & I learn English because I want to find better jobs. & 7 & 1.79 \\
\hline 15 & In the future, I will need English for my desired job. & 4 & 1.52 \\
\hline 16 & Studying English leads to anxiety & 20 & 2.69 \\
\hline 17 & Studying for tests like the TOEIC and TOEFL leads to anxiety & 18 & 2.4 \\
\hline 18 & I am sure I will be able to learn English well. & 16 & 2.15 \\
\hline 19 & I am happy with the level of English I have achieved & 24 & 3.15 \\
\hline 20 & Too much emphasis is placed upon English in Korea. & 5 & 1.54 \\
\hline 21 & In Korea, English teaching methods are effective. & 22 & 2.84 \\
\hline 22 & Korean people need to learn English & 8 & 1.92 \\
\hline 23 & Being fluent in English is a sign of status. & 19 & 2.58 \\
\hline 24 & If the instructor uses positive communication, my attitude will become more positive. & 3 & 1.46 \\
\hline & higher the rank, the more the participants agreed with the statement. & & \\
\hline
\end{tabular}




\section{Students' Feelings towards English in Korea}

What are students' feelings towards English in Korea? Participants were asked to respond to the following statements concerning the study of English in Korea, by rating their agreement on a four-point scale:

- I feel uneasy when speaking English to a native speaker.

- I feel comfortable when using English.

- It embarrasses me to volunteer answers in English class.

- I wish I could speak fluent English.

- I really enjoy studying English.

- I would learn English even if it were not a compulsory subject in university.

- In the future, I will need English for my desired job.

- Studying English leads me to feel anxiety.

- Studying for tests, like the TOIEC and TOEFL, leads to anxiety.

- I am sure I will be able to learn English well.

- I am happy with the level of English I have achieved.

- Too much emphasis is placed upon English in Korea.

- Korean people need to learn English.

- Being fluent in English is a sign of status.

As shown in table 5, participants strongly agreed that they wish they could speak fluent English with a mean of 1.02. There was also a high degree of agreement that they will need English for their desired job, that too much emphasis is placed upon English in Korea, and that they would continue to study English even if it weren't a compulsory subject in university, with means of $1.52,1.54$, and 1.60 in that order. It was also found participants agreed that Korean people need to learn English, that they feel uneasy when speaking English to a native English speaker, that they really enjoy studying English, and that they are sure they will be able to learn English well, with means of $1.92,1.94,2.02$, and 2.15 respectively.

It was found participants showed no clear signs of agreement or disagreement that studying for tests, such as the TOEIC and TOEFL, leads to anxiety and that being fluent in English is a sign of status, with means of 2.40 and 2.58 correspondingly.

Participants showed signs of disagreement that studying English leads to anxiety, that it embarrasses them to volunteer answers in English class, that they feel comfortable using English in class, and that they are happy with the level of English they have achieved, with means of $2.69,2.71,2,98$ and 3.15 respectively.

\section{Reasons Students Study English}

What are the most important reasons for students studying English? Participants were given six choices for studying English and asked to rank them in importance from one to six. The six options were:

- To get a better job.

- To pass important English examinations (TOEIC, TOEFL, etc.)
- For personal enjoyment.
- To understand another culture.
- To meet people from different countries.
- To study in another country.

As shown in table 6, a mean was taken for all the results finding that getting a better job was found as the most important reason for studying English, with a mean of 2.04. The rest of the responses in order of importance were: to meet people from different countries (3.21); for personal enjoyment (3.50); to pass important English examinations (3.58); to study in another country (3.97); and last, to understand another culture (4.69).

Table 6. Order of importance in why English is studied

\begin{tabular}{|c|c|c|}
\hline & \multicolumn{2}{|c|}{$(\mathrm{N}=52)$} \\
\hline $\begin{array}{c}\text { To get a better job } \\
\text { TOEFL, etc.) }\end{array}$ & 1 & Mean \\
\hline $\begin{array}{c}\text { To pass important English examinations (TOEIC, } \\
\text { For personal enjoyment }\end{array}$ & 4 & 3.58 \\
\hline To understand another culture & 3 & 3.5 \\
\hline To meet people from different countries & 6 & 4.7 \\
\hline To study in another country & 2 & 3.21 \\
\hline
\end{tabular}

Taking gender into account, table 7 , results were found to be similar; the most significant difference being female students put much more emphasis on learning English in order to study in another country, ranking it third, with a mean of 3.41, where males ranked it fifth, with a mean of 4.23. The only other difference of any interest was that females placed less importance on studying English in order to get a better job, with a mean of 2.29 , whereas males found getting a better job more important, with a mean of 1.91.

Table 7. Order of importance in why English is studied by gender

\begin{tabular}{|c|c|c|c|c|}
\hline & \multicolumn{2}{|c|}{$\begin{array}{c}\text { Male } \\
(\mathrm{N}=35)\end{array}$} & \multicolumn{2}{c|}{$\begin{array}{c}\text { Female } \\
(\mathrm{N}=17)\end{array}$} \\
\hline & Rank & mean & Rank & Mean \\
\hline To get a better job & 1 & 1.91 & 1 & 2.29 \\
\hline $\begin{array}{c}\text { To pass important English } \\
\text { examinations (TOEIC, } \\
\text { TOEFL, etc.) }\end{array}$ & 4 & 3.51 & 5 & 3.71 \\
\hline For personal enjoyment & 3 & 3.43 & 4 & 3.65 \\
\hline $\begin{array}{c}\text { To understand another } \\
\text { culture }\end{array}$ & 6 & 4.66 & 6 & 4.76 \\
\hline $\begin{array}{c}\text { To meet people from } \\
\text { different countries }\end{array}$ & 2 & 3.26 & 2 & 3.12 \\
\hline To study in another country & 5 & 4.23 & 3 & 3.4 \\
\hline
\end{tabular}

\section{Roles of Extrinsic Motivation and Intrinsic Motivation}

Are students more intrinsically or extrinsically motivated? Participants were asked to rate their agreement to the following statements on a four-point scale:

- Studying English will help me understand people from around the world.

- I would like to become similar to people who speak English as a native language. 
- I learn English because I want to pass examinations (TOEIC, TOEFL, etc.).

- I learn English because I want to find better jobs.

As shown in table 8 , it was found that extrinsic and intrinsic reasons for studying English received similar levels of importance. The two intrinsic motivation statements, studying English will help me understand people from around the world and I would like to become similar to people who speak English as a native language, had means of 1.94 and 2.00 respectively. The two extrinsic motivation statements, I learn English because I want to pass examinations and I learn English because I want to find better jobs, had respective means of 2.04 and 1.79. Again, it was found that getting a job was an important factor in learning English; however, it was not clear that either extrinsic or intrinsic motivation was found more important than the other.

Table 8. Rank orders and mean for participants' responses intrinsic and extrinsic factors

\begin{tabular}{|c|c|c|}
\hline & \multicolumn{2}{|c|}{$(\mathrm{N}=52)$} \\
\hline $\begin{array}{c}\text { Studying English will help me to understand people } \\
\text { from all over the world. }\end{array}$ & 2 & 1.94 \\
\hline $\begin{array}{c}\text { You would like to become similar to people who } \\
\text { speak English as a native language }\end{array}$ & 3 & 2 \\
\hline $\begin{array}{c}\text { I learn English because I want to pass examinations } \\
\text { (TOEIC, TOEFL) }\end{array}$ & 4 & 2.04 \\
\hline I learn English because I want to find better jobs. & 1 & 1.79 \\
\hline
\end{tabular}

\section{Discussion}

Students appear to have a positive attitude towards studying English. While the reasons themselves were not researched, results seem to support Kobayashi[24] that females tend to have a more positive attitude towards language study, in this instance the language being English. However, both populations showed a positive attitude and there was not a large difference in attitude. The results regarding attitude in relation to previous private academy attendance were found to be very interesting. The reason for the less positive attitude amongst students who had attended academies for over two years could possibly be because of being forced to study English too much, as well as too much emphasis being placed upon English. Students who had only studied for a year or two might not have reached a level of frustration of having to attend a private academy for so long. The general attitude of students who have not attended private academies was similar to students who have attended for over 2 years, though slightly better. Again, it is important to note that all three groups share a positive attitude towards studying English.

These results in a way support what students reported when asked if they agree that studying English at private academies will have a positive effect on their attitudes. Students agreed to the statement that their attitude would become more positive if they were to study at a private academy. This seems to support what was found to a point, but contradicts the evidence showing that students who have attended private academies for more than two years have a less positive attitude than their one to two year counterparts.

Looking at attitude towards Americans and American culture, it was found to not support Lee's [28] findings of a general negative attitude towards Americans. The results of this study found that most participants agreed to have positive views towards Americans and American culture. The divergence from Lee's [28] findings could very well be due to the near cyclical changes in attitudes towards America, and 2002 was a time of strong anti-Americanism in Korea. This study too, could have very had different results if it had been conducted during one of the frequent times of strong anti-Americanism within Korea. Looking at the results that were obtained in this study and examining participants' views towards Americans and American culture and its relation to general attitude towards studying English, the results were relatively clear. Participants who strongly agreed to having a positive view towards Americans and American culture did not have the best attitude towards studying English, but this group's attitude towards studying English was, however, better than the group of participants reporting the least positive view towards Americans and American culture. These results may not be completely reliable due to the low number of participants that reported strongly agreeing to have a positive view towards Americans and American culture. The participants who agreed to having positive views towards Americans and American culture had the best attitude towards studying English, much better than the groups who, interestingly, strongly agreed to having a positive view towards Americans and American culture and also those who disagreed to having a positive view. These results clearly indicate that while the relation might not be as strong as expected, students' views towards Americans and American culture does affect attitude towards studying English.

Looking into factors which affect students' attitudes towards studying English, participants reported strongly favouring having a native English speaking teacher over having a Korean English teacher. These findings support the research of Moussu and Braine[37] which found that among ELLs from six different language groups, Koreans showed the most negativity towards non-native English speaking teachers and also found that Korean students had the least respect and admiration for non-native English speaking teachers and found them to have less authority in the classroom when compared to native English speaking teachers. This comes as no surprise as students also disagreed that English teaching methods in Korea are effective. These results tend to support what Chang[32] and Lee[28] argued being that Korean teaching methods are not in sync with students' desires for a more communicative approach, which is what is usually provided with a native English speaking teacher. Supporting what Chang[32] found, participants strongly agreed that an instructor using positive 
communication will result in their attitude also becoming more positive.

Investigating students' attitudes towards English in Korea, some interesting results were found. It was shown that not only did participants think Koreans need to learn English, they also think that too much emphasis is placed upon English in Korea. This is interesting as they seem almost contradictory, but perhaps this just reveals how much over emphasis really is put upon the study of English in Korea. Conceivably, supporting Chang's[32] argument, there may just be too much emphasis put upon learning English that it has become almost unreasonable. When taking into account participants' feelings towards needing English for future employment, the emphasis seems justified as there was very strong agreement that English will be needed for participants' desired jobs. In contradiction to Chang's [32] research, this study showed that studying English, and even studying for important examinations, such as the TOEIC and TOEFL test, did not lead to feeling anxiety. Results have shown that participants have even leaned towards disagreement in that studying English leads to feeling anxiety.

Regarding the level of English ability students have achieved, this study has supported Lee's[28] argument that students are not happy with the level of English they have achieved, which also related to how teaching methods in Korea are not effective. Of all the different Likert-scale questions, whether participants are happy with the level of English they have achieved is the one the students disagreed with most. However, on a positive note, participants tend to agree that they will be able to learn English well. In regards to this feeling, the strongest sense of agreement that was shown on the survey was that participants strongly agree to wish they were fluent in English. With this desire and confidence in the ability to learn English well, this seems to be a very positive result.

Participants desire to study English also looks positive. Participants report agreement that they really enjoy studying English and show strong agreement that they would continue to study English even if it were not a compulsory subject in university. It seems that students overall have a positive outlook on English when desire to study, enjoyment, aspiration to be fluent, and confidence in ability are taken into consideration.

When looking at actual use of English, it was shown that the participants are not comfortable when using English and feel uneasy when speaking to native English speakers. On the other hand, the participants do not feel too embarrassed to volunteer answers in English class. Still, it would seem that being uncomfortable when using English would suggest a sense of anxiety. So, although studying English may not lead to anxiety, it would appear that actually using English may result in anxiety.

Looking into why students study English and what is most important to them, the survey participants were asked to rank in order the most important reasons for studying English. Getting a better job (mean $=2.04$ ) was found to be the most important reason for studying English, more than one full point ahead of the second most important reason, to meet people from different countries (mean $=3.21)$. It appears that an extrinsically motivated factor is the most important reason for studying English, but an intrinsically motivated factor was the second most important reason. Studying for personal enjoyment and to pass examinations (TOEIC or TOEFL) are the next two most important reasons with very similar means. Here, examples of intrinsic and extrinsic motivation are seen as being similar in importance. An extrinsically motivated reason is seen as the fifth most important factor in studying English, in studying English for the chance to study abroad. Last, the intrinsically motivated factor of studying English to understand another culture is seen. As can be seen from these results, looking at the mean of the three extrinsic motivational factors, there is a mean of 3.19 , which play a more prominent role than intrinsic motivational factors, with a mean of 3.80. However, if looking at the ranking of what is most important, two of the three most important reasons are intrinsic. With these results, it can be difficult to gauge whether extrinsic motivation or intrinsic motivation is more important. The only clear results are that getting a job is by far the most important reason for studying English and understanding another culture is the least important reason. This is consistent with Lee[28] who stated that university students are most concerned with learning English to better their careers. With extrinsic and intrinsic motivation both deemed to be important to participants, it would seem that there is a healthy combination of motivation keeping students studying English. As Rubenfeld[8] showed, both extrinsic motivation and intrinsic motivation are useful within the classroom and as the results in this study show, it would appear that students look as if they are on course for success in their studies of English.

Taking gender into account, different results are shown. While the most important reason for studying English is the same, females place much less importance upon getting a better job. Females place more importance into meeting people from different countries and studying abroad, supporting Kobayashi's [24] argument. While the reasons for these results were not pursued, finding similar results may allow us to generalize that perhaps females have less social constraints and are more likely to try to use language as a way to better their lives, especially in a country where in many instances males automatically start off at a higher wage for the same position, as is the case in Korea.

As it has been shown, the Korean university students who participated in this study appear to have a positive outlook on the study of English, with both, males and females, and students who have and have not previously attended private academies all reporting mostly having a positive attitude towards the study of English. It was also shown that students have a more positive attitude towards native English speaking teachers over Korean English teachers and that a teacher communicating more positively creates a more positive attitude amongst students. It was also reported that current teaching methods in Korea are not seen as being 
effective. English was also seen as being very important for Koreans, while at the same time seen as having too much emphasis placed upon the study of the language itself. It was reported that actually using the language outside of the classroom made students feel uneasy and speaking to native English speakers in English was uncomfortable. Students also appeared to be unhappy with their level of English, but did have a positive outlook to their future potential in learning the language. Getting a better job was also seen as the most important reason for studying English; however, extrinsic motivation and intrinsic motivation seemed to both play a prominent role in the motivation of students.

\section{Conclusions}

This study aimed to find what effects the long-term pressure to learn English has done to the attitudes of ELLs in Korea while also looking at what motivates them, and hopefully, it can contribute towards finding ways to improve the overall attitude towards learning English. English education is important in Korea and keeping students attitudes positive towards learning English is very important. As opposed to what was originally anticipated, it appears that students have a positive overall attitude towards learning English, however there is room for improvement. Giving students more exposure to English, even in after-school academies, is an important way to keep students positive. However it is also important not to put too much pressure onto the students to learn English and have them spend too much time in the classroom. This would mean limiting time spent in after-school academies.

The government's move to reduce the number of native English speaking teachers in Korean public schools could negatively affect the attitudes of ELLs as students show a strong preference for learning from native speakers. The communicative method that most native English speaking teachers use is likely one of the reasons for this preference, so perhaps Korean English teachers should be encouraged to use a more communicative approach in the classroom to further improve attitudes towards them in the classroom and produce a more positive environment.

Cultivating a positive view of foreign cultures and America would also strengthen students' desires to learn English. While there is already a general positive view towards Americans and American culture at the time of research, this needs to be carefully maintained to make sure that students still keep a positive overall attitude. Aside from just keeping a positive attitude towards learning English, promoting a positive attitude towards foreign cultures will only help to give students more intrinsic reasons for learning English.

Making sure that students have intrinsic, as well as extrinsic, motivation towards learning English will also help to maintain positive attitudes and help students learn. While students already appear to show both intrinsic and extrinsic reasons for learning English, we should be careful not to put too much emphasis on only the extrinsic reasons and we should foster intrinsic reasons as much as possible.

\section{Recommendations for Further Research}

More research on this topic could be done using a larger number of participants, as well as participants from different universities at varying levels. The limited number of participants in this study narrowed the ability to make generalizations of the population at large, especially in areas where only a limited number of participants reported certain responses. The possibility of delving into more descriptive qualitative data would also help to clarify the results and why the current situation is the way it is. Possibly, trying to understand what can be done to get students' results to match their desired levels and how this can be implemented more successfully into the education system could be pursued. Overall, continued research on this topic could be used to make positive changes on the current situation of English language education in Korea.

\section{REFERENCES}

[1] Kim, T.J. "Kids Say Learning English Stressful." The Korea Times. 7 June 2007. Web. <www.koreatimes.com>.

[2] Hong, K.W. "English Haunts Korea." The Korea Times. 2 July 2008. Web. <www.koreatimes.com>

[3] "Petition Protests English Expansion Plan." Joongang Daily. 26 Nov. 2008. Web. <http://koreajoongangdaily.joins.com>.

[4] Ryall, J. "Children's surgery to speak better English." The Daily Mail. Web. <www.dailymail.co.uk>

[5] Choe, S.H. "S. Koreans Accent Surgery in Bid for Flawless English" The LA Times. 18 Jan. 2004. <www.latimes.com>

[6] Bae, J.S. "Health Tops Issues Among Office Workers." The Korea Times., 2 December 2007. Web. $<$ www.koreatimes.com>

[7] Park, J.K. 'English Fever' in South Korea: its history and symptoms. English Today, 25, pp. 50-57; 2009.

[8] Rubenfeld, S, Sinclair, L, Clement, R. Second language learning and acculturation: The role of motivation and goal content congruence. Journal of Language and Social Psychology. Vol. 26, No. 2.; 2007.

[9] Deci, E.L. The psychology of self-determination. Toronto: Lexington Books; 1980.

[10] Deci, E.L. and Ryan, R.M. Intrinsic motivation and self-determination in human behavior. New York: Plenum; 1985.

[11] Vansteenkiste, M., Simons, J., Lens, W., Sheldon, K.M. and Deci, E.L. Motivating learning, performance, and persistence: The synergistic effects of intrinsic goal contents and 
autonomy-supportive contexts. Journal of Personality and Social Psychology, 87, pp. 246-260; 2004.

[12] Sheldon, K. M., Ryan, R.M., Deci, E.L. and T. Kasser. The independent effects of goal contents and motives on well-being: It's both what you pursue and why you pursue it. Personality and Social Psychology Bulletin, 30, pp. 475-486; 2004.

[13] Liu, M. Motivation in Chinese University EFL Learners in Varying Learning Contexts. TESL Reporter, 45, (2) pp 17-39; 2012.

[14] Gardner, R.C. Social psychological aspects of second language acquisition. In H. Giles and R. St. Clair (eds.), Language and social psychology. Oxford: Basil Blackwell, pp. 193-220; 1979.

[15] Donà, G. and Berry, J.W. Acculturation attitudes and acculturative stress of Central American refugees. International Journal of Psychology, 29, pp. 57-70; 1994.

[16] Downie, M., Koestner, R., ElGeladi, S. and Cree, K. The impact of cultural internalization and integration on well-being among tri-cultural individuals. Personality and Social Psychology Bulletin, 30, pp. 1-10; 2004.

[17] Zhou, W. Motivation and language learning in the context of China. Sino-US English Teaching. Vol. 5, No. 4, USA; 2008.

[18] Kormos, J., Csizer, K. Age-Related Differences in the Motivation of Learning English as a Foreign Language: Attitudes, Selves, and Motivated Learning Behavior. University of Michigan. Language Learning, 58:2, USA; 2008.

[19] Crystal, D. English as a Global Language (2 ${ }^{\text {nd }}$ Ed.) Cambridge: Cambridge University Press; 2003.

[20] Widdowson, H.G. The Ownership of English. IATEFL annual conference report, Plenaries 1993. Whitstable, UK; 1993.

[21] Yashima, T. Willingness to communicate in a second language: The Japanese EFL context. Modern Language Journal, 86, 54-66; 2002.

[22] Lamb, M. Integrative Motivation in a Globalizing World. System, Vol. 32, 3-19; 2004.

[23] Park, H. and Lee, A.R. L2 Learners' Anxiety, Self-Confidence and Oral Performance. 10th Conference of Pan-Pacific Association of Applied Linguistics, Edinburgh University, conference proceedings. pp. 197-208; 2005.
[24] Kobayashi, Y. The Role of Gender in Foreign Language Learning Attitudes: Japanese female students' attitudes towards English learning, Gender and Education. Vol. 14, No. 2, pp. 81-197; 2002.

[25] Yee, M., Young, C. Macao students' attitudes toward English: a post-1999 survey. World Englishes. Vol. 25, No. 3/4, pp. 479-490; 2006.

[26] Friedrich, P. English in Argentina: attitudes of MBA students. World Englishes. Vol. 22, No. 2, pp. 173-184; 2003.

[27] Ryu, K.N. A Study on the Affective Variables in Learning a Foreign Language: Attitudes and Motivation. Kangwon National University, Korea; 2004.

[28] Lee, J.S. EFL Learners' Motivation and Attitude Toward English Language and American People. Dongguk University, Korea; 2002.

[29] Duvernay, N. Motivation and Anxiety in the Korean EFL Classroom. Korea University; 2007.

[30] Flattery, B. Language, Culture, and Pedagogy: An Overview of English is South Korea. University of Toronto; 2007.

[31] Kim, T.Y. Motivation and attitudes toward foreign language learning as socio-politically mediated constructs: The case of Korean high school students. The Journal of Asia TEFL. Vol. 3, No. 2, pp. 165-192; 2006.

[32] Chang, K.S. Korean Learners' Attitude toward the English Boom Phenomenon and Learner Anxiety. Keimyung University, Korea; 2004.

[33] Scovel, T. The Effect of Affect on Foreign Language Learning: A Review of the Anxiety Research. Language Learning. Vol. 28, No. 1, pp. 129-142; 1978.

[34] Liu, H.J. Understanding EFL Undergraduate Anxiety in Relation to Motivation, Autonomy, and Language Proficiency. Electronic Journal of Foreign Language Teaching, Vol. 9, No. 1, pp 123-139; 2012.

[35] Yim, S.Y. and Yu, Y.L. Validating the English learning anxiety scale for primary school students in Korea. English Teaching, 66(2), pp. 101-121; 2011.

[36] Dörnyei, Z. Motivational Strategies. Cambridge: Cambridge University Press; 2001.

[37] Moussu, L. and Braine, G. The Attitudes of ESL Students Towards Nonnative English Language Teachers. TESL Reporter 39, 1, pp. 33-47; 2006. 